\title{
A Flowing Reaction Vessel ${ }^{*}$
}

\author{
by \\ Allen W. KnighT ${ }^{\star \star} \&$ Wayne T. Swallow \\ Michigan State University
}

INTRODUCTION

Information is sparse on oxygen consumption of lotic invertebrate forms, partially from lack of interest but mostly from lack of instrumentation for measuring the oxygen consumption of lotic organisms in a flowing-water system. Existing methods utilizing "standard technique" does not necessarily provide data that can be extrapolated with ecological significance. Questions arise as to the effects of current stimulus and the substrate with which the organism is naturally associated as well as the reactions of the test organism to a constant shaking, as with standard manometric technique.

New techniques were clearly necessary for determining the normal capabilities of the test organism and obtaining reliable data on its ecological distribution and physiology. The apparatus described herein was developed to evaluate oxygen consumption under conditions approaching field conditions. Oxygen consumption has been measured by other than manometric techniques with respirometers utilizing flowing water designed for invertebrates (WINGFIELD, 1939; AMB ÜHL, 1959; ZAHNER, 1959; ERIKSEN \& FELdMETH, 1967).

Aquatic organisms possessing no special structural features which aid in resisting the transporting tendency of water movement habitually seek the protected sides and interstices between rocks. The many invertebrate forms living in this zone thus normally encounter only low current velocities. A current was therefore produced in the

\footnotetext{
*This investigation was supported in part by Federal Water Pollution Control Administration Grant WP-01178. Contribution No. 182, W. K. Kellogg Biological Station of Michigan State University.

$\star \star$ Present address: Department of Water Science and Engineering, University of California, Davis, California 95616.

Received March 13th, 1969.
} 
"flowing reaction vessel" which would simulate the water flow that many aquatic insects experience in their natural habitat.

\section{METHODS AND MATERIALS}

A "flowing reaction vessel", of Pyrex glass was constructed to have a total volume of $350 \mathrm{ml}$. The basic design is that of an oval composed of detachable halves. The halves terminate in four glass joints (Sargent S-40223, size F). Greased O rings (Sargent size 14-124) are inserted between the glass joints, and the two sections of the stream are secured together with glass grinding clamps (Sargent S-40222, No. 35). The O rings are laced with stainless-steel wire (dia $\cong .025 \mathrm{~cm}$ ) at intervals of three to four $\mathrm{mm}$ to isolate the organism(s) from the action of the current producing spinfin (figs. 1 and 2).

The spinfin is housed in a concavity in the current-producing portion of the vessel. Also situated in this portion are two sidearms, $\mathrm{KOH}$ reservoirs, and the attachment of the vessel to the respirometer. The sidearms and neck are equipped with ground-glass fittings. The neck serves as a lead connecting to a differential respirometer (Gilson model GRP-14). The sidearms are sealed with glass plugs. A $\mathrm{KOH}$ solution is used as a $\mathrm{CO}_{2}$ absorbant, $0.2 \mathrm{ml}$ being inserted into each sidearm, which is provided with filter-paper wicks. All joints are generously lubricated with stopcock grease to assure an air-tight system.

The water current is produced in the vessel with a Bel-Art Alnico V-Spinfin (F-37125), propelled by a TRI-R magnetic stirrer (MS7S) connected to a TRI-R speed-control box, 115 volt, 50/60 cycle AC (MS-7AB) (figs. 1 and 2). The vessel current is regulated over a limited range with the speed-control box, which remains fixed.

The voltage-control unit is composed of a variable transformer and an $\mathrm{AC}$ voltmeter. The voltmeter supplies a desired input voltage to the speed-control box.

The water-current velocities produced in the vessel, over a limited range, were a function of the input voltage to the speed-control box.

The current velocity was determined by injecting fluorescein dye into one of the vessel sidearms and timing its passage between two points. The maximum water velocity attainable in the vessel is 11 $\mathrm{cm} / \mathrm{sec}$.

During experimental evaluation, water volume was kept constant so as to maintain uniform current velocities. The substrate (sterilized crushed brick) volume was determined by water displacement and held constant in all experimental evaluations. The volume of the test organism(s) (hellgrammite, Corydalus cornutus (L.)) was determined 


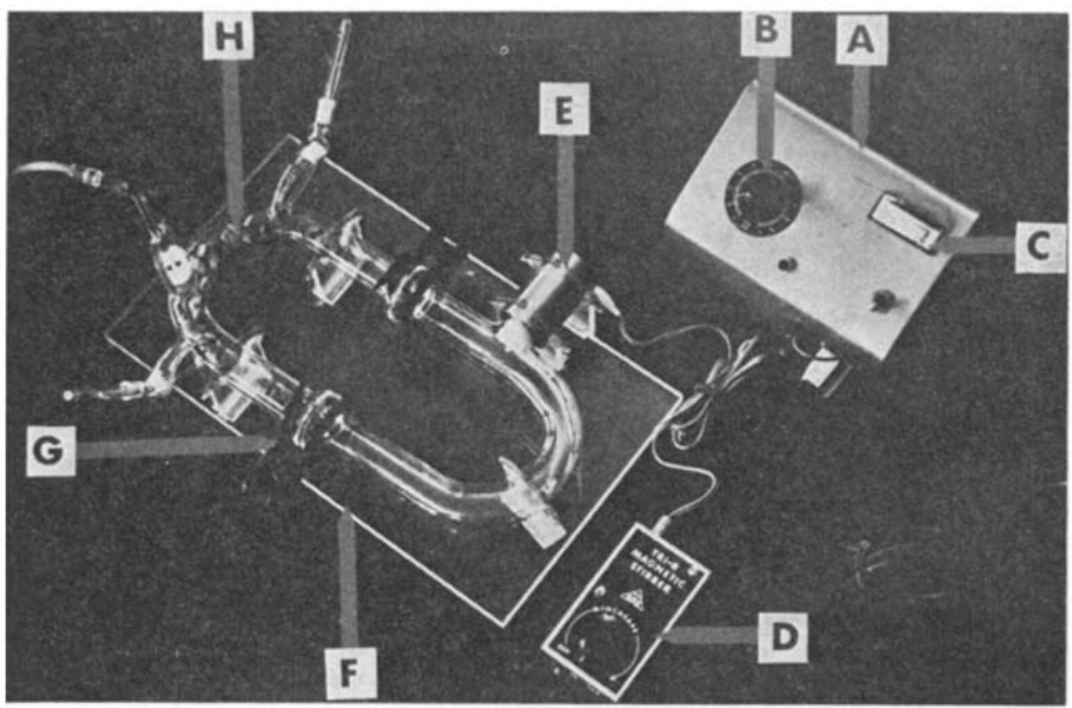

Fig. 1. Photograph illustrating reaction vessel-and-current-regulating apparatus, $A$, voltage control unit; $B$, variable transformer; $C$. AC voltmeter; $D$, speed-control box; E, magnetic stirrer; F, flask cradle; $G$, glass grinding clamp; and $\mathrm{H}$, substrate.

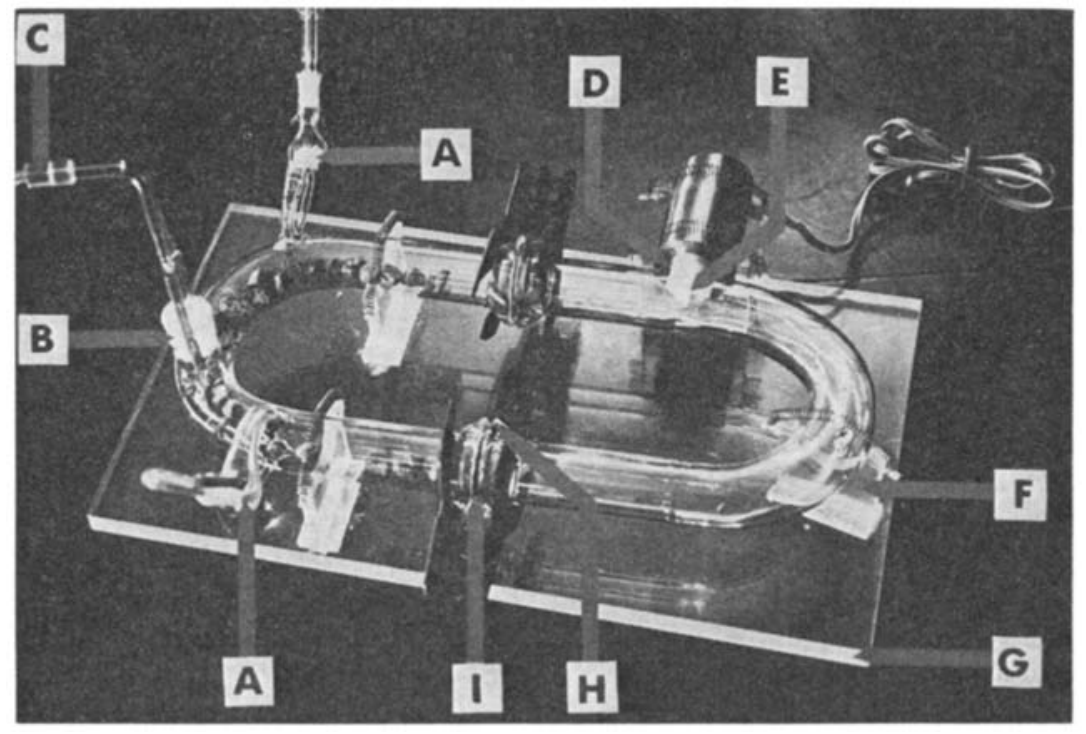

Fig. 2. Photograph of reaction vessel and cradle. A, sidearms (KOH reservoirs); $\mathrm{B}$, neck for attaching respirometer; $\mathrm{C}$, tubing to respirometer; $\mathrm{D}$, spinfin well; $E$, spinfin; $F$, cradle upright; $G$, cradle base; $H$, glass joints; and $I, O$ ring. 
prior to oxygen consumption evaluations. The combined displacement of the organism and the test water was brought up to $210 \mathrm{ml}$ in all experimental evaluations.

To retain the components of the apparatus in proper alignment, a cradle was designed and constructed from Plexiglass. The base was fabricated from Plexiglass ( $8 \times 14 \times \frac{1}{2}$ inch) with uprights $\left(2 \times 2 \times \frac{1}{4}\right.$ inch) bonded to the base with base solvent. Semicircles in the upper portion of the uprights accommodated the curvature of the vessel. The vessel was anchored to the cradle with springs. The entire apparatus was introduced into the water bath of a Gilson respirometer, the shaking apparatus having previously been removed to accommodate the vessel and cradle. The apparatus was secured in the water bath with a series of Sargent utility $V$ clamps, extension clamps, and clamp holders.

The test organisms were acclimated in the vessel for 14 to 16 hours before experimental evaluation, and oxygen consumption evaluations were then obtained for three separate one-hour periods. Hellgrammite oxygen consumption rates were evaluated at $20^{\circ}$ and $30^{\circ} \mathrm{C}$.

Upon completion of an evaluation, each hellgrammite was removed from the vessel and killed in hot water. Each animal was placed in a Cenco drying oven $\left(104^{\circ} \mathrm{C}\right)$ for 24 hours, after which its dry weight (mg) was determined on a Mettler electronic balance. The respirometer readings in microliters, were converted to standard conditions by the following (Gilson Medical Electronics Operating Manual):

$$
\begin{aligned}
& \text { Multiplying factor }=\frac{(273)\left(\mathrm{P}_{\mathrm{b}}-3-\mathrm{Pw}\right)}{(\mathrm{t}+273)(760)} \\
& \text { where: } 273=\text { absolute zero }\left(273^{\circ} \text { Kelvin }\right) \\
& 760=\text { standard barometric pressure }(\mathrm{mm} \mathrm{Hg}) \\
& \mathrm{t}=\text { water-bath temperature in } \mathrm{C}^{\circ} \\
& \mathrm{P}_{\mathrm{b}}=\text { barometric pressure (in. } \mathrm{Hg} \times 25.4 \mathrm{~mm} / \text { in.) } \\
& \mathrm{Pw}=\text { water-vapor pressure at } \mathrm{t}
\end{aligned}
$$

\section{Discussion}

The "flowing reaction vessel" described herein is an attempt to develop a technique for evaluating the oxygen consumption of lotic organisms. The limited data collected thus far appear rather consistent.

The apparatus presently has an operating water flow range from 3 to $11 \mathrm{~cm} / \mathrm{sec}$. This limited water current approximates the water flow that the test organisms encounter in their natural habitat. The vessel is currently being modified to obtain water current velocities 
up to $100 \mathrm{~cm} / \mathrm{sec}$. The faster current would be necessary for forms that inhabit the upper surfaces of rocks and are exposed to faster flow.

Although the substrate was not varied in preliminary evaluation of the apparatus, it can be altered in size and consistency. This feature would lend itself to organism-substrate relationship studies. Further, constructing the vessel in halves will make it easy to build animal chambers of various sizes.

The vessel lends itself to numerous pesticide and bioassay problems. Teflon coated metallic cups with precisely measured amounts of pesticide or other toxicant could be suspended from the upper portion of the vessel with a magnet. After the unmodified metabolic rate was established, the cups could be upended to release the material to be evaluated.

The oxygen-consumption values obtained with the "flowing reaction vessel" were compared with data obtained with a Gilson differential respirometer complete with shaking flasks. The Mann Whitney U test (SIEGEL, 1956) was employed to compare the mean respiration rates of two populations of similarly sized hellgrammites evaluated by the "flowing reaction vessel" and shaking-flask method. A test on the organisms at $20^{\circ} \mathrm{C}$ showed $.002 \leq \mathrm{p}(\mathrm{U} \leq 3) \leq .02$. By inspection the "flowing reaction vessel" data can be seen to be greater than the data obtained by the shaking-flask method. A test performed on the $30^{\circ} \mathrm{C}$ data revealed $\mathrm{P}(\mathrm{U} \leq 0) \leq .056$. From this it can be said that the data do not support the hypothesis that both methods of measuring respiration yield similar results. Caution must be advanced here, however, because the "flowing reaction vessel" data are still somewhat tentative. In-depth studies will be required before conclusive statements can be considered valid concerning the effects of current on metabolic rate.

\section{SUMMARY}

A device for measuring the oxygen consumption of lotic organisms was designed and constructed. The apparatus maintains a water current in the respiratory vessel. Results obtained with flowing water were compared with results obtained by standard manometric techniques with oscillating flasks. Respiratory rates were significantly higher with the new apparatus in measuring the respiration of two similar populations of the hellgrammite (Corydalus cornutus (L.)). 


\section{ZUSAMMENFASSUNG}

Ein Apparat zur Messung der Sauerstoffaufnahme von fluvialen Organismen wurde entworfen und konstruiert. Der Apparat betreibt eine Wasserströmung in dem Reaktionsgefäß. Unter fließendem Wasser erzielte Resultate wurden mit Resultaten aus Versuchen mit üblichen manometrischen Verfahren mit oscillierenden Flaschen verglichen. Aufnahmemengen waren wesentlich höher mit dem neuen Apparat in Atmungsmessungen an zwei ähnlichen Bevölkerungen der Verschuchsorganismen (Corydalus cornutus (L.)).

\section{ACKNOWLEDGEMENTS}

The authors thank Dr. Herman H. Slatis and Dr. William E. COOPER, both of the Dept. of Zoology, Michigan State University, for statistical consultation; ROBERT LUNDQUIST, for construction of the voltage-control unit; and WARREN ALWARD, for procurement and acclimation of the test organisms.

\section{REFERENCES}

AмBüHL, H. - 1959 - Die Bedeutung der Strömung als ökologischer Faktor Schweiz. A. Hydrol. 21: 133-264.

ERIKSEN, C. H. \& FELDMETH, C. R. - 1967 - A water-current respirometer. Hydrobiologia 29: 495-504.

SIEGEL, S. - 1956 - Nonparametric statistics for the behavioral sciences. McGraw-Hill Book Co., N.Y.

WINGPIELD, C. A. - 1939 - The function of the gills of mayfly nymphs from different habitats. F. Exp. Biol. 16: 363-373.

ZAHNER, R. - 1959 - Über die Bindung der mitteleuropäischer Calopteryx Arten (odonata - zygoptera) an den Lebensraum des strömenden Wassers. Int. Rev. Hydrobiol. 44: 51-130. 